\title{
Acute Ischemic Stroke: A Review of Imaging, Patient Selection, and Management in the Endovascular Era. Part II: Patient Selection, Endovascular Thrombectomy, and Postprocedure Management
}

\author{
Sharath Kumar G.G. ${ }^{1}$ Chinmay P. Nagesh ${ }^{1}$ \\ ${ }^{1}$ Department of Diagnostic and Interventional Neuroradiology, \\ Apollo Hospitals, Bangalore, Karnataka, India
}

\begin{abstract}
Address for correspondence Chinmay P. Nagesh, MD, DNB, FRCR, DM, Department of Diagnostic and Interventional Neuroradiology, Apollo Hospitals, Bangalore, Karnataka, India

(e-mail: drchinmaynagesh@gmail.com).
\end{abstract}

\begin{abstract}
Appropriate patient selection and expedient recanalization are the mainstay of modern management of acute ischemic stroke (AIS). Only a minority of patients (7-15\%) of patients are eligible for endovascular therapy. Patient selection may be time based or perfusion based. Central to both paradigms is the selection of a patient with a small core, a significant penumbra that can be differentiated from areas of oligemia. A brief review of patient selection methods is presented. Endovascular thrombectomy techniques using stentrievers or aspiration catheters have now become the treatment of choice for AIS with large vessel occlusion. A range of devices, each with its own advan-

Keywords

- stroke

- mechanical

thrombectomy

- aspiration

thrombectomy tages and disadvantages, are available in the market for the neurointerventionist to choose. Techniques vary between devices and between operators, but standardization and protocolization are important within each center. Complications must be anticipated to be avoided. Once reperfusion is achieved, outcomes must be safeguarded with competent postprocedure management to prevent secondary brain injury. These aspects are reviewed in this article.
\end{abstract}

\section{Introduction}

Patient selection is crucial in optimizing the balance between achieving good functional outcomes and avoiding complications in patients with acute ischemic stroke (AIS). Only a minority (7-15\%) of patients with AIS are eligible for mechanical thrombectomy (MT). ${ }^{1-3}$ In this precious population, recanalization must therefore be rapid, effective, and safe. MT ${ }^{4}$ may be achieved by myriad techniques and devices, and the interventional neuroradiologist must be conversant and resourceful in this high-stress situation. Once reperfusion is achieved, outcomes must be safeguarded with competent postprocedure management to prevent secondary brain injury. We review these aspects in this article.

\section{Medical Acute Reperfusion Treatments}

Intravenous thrombolysis (IVT): IVT is the mainstay of treatment for almost any AIS syndrome with a measurable deficit. Intravenous (IV) infusion of recombinant tissue-type plasminogen activator (IVrt-PA or alteplase) is approved for use within 4.5 hours of onset. ${ }^{4}$ Though the standard dose is $0.9 \mathrm{mg} / \mathrm{kg}$, low-dose regimens using only $0.6 \mathrm{mg} / \mathrm{kg}$ have been found to be noninferior in Asian populations and may reduce costs of treatment.5,6 Tenecteplase, a drug with a similar profile, has the advantage of single bolus administration $(0.4 \mathrm{mg} / \mathrm{kg}$ ). Though not yet FDA (Food and Drug administration) approved for use in AIS, results of the ATTEST (Alteplase-Tenecteplase Trial Evaluation for Stroke Thrombolysis) and EXTEND-IA (EXtending the time
DOI https://doi.org/

10.1055/s-0038-1675882

ISSN 2457-0214.
C 2018 by Indian Society of Vascular and Interventional Radiology
License terms

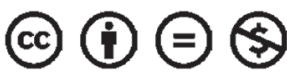


for Thrombolysis in Emergency Neurological Deficits with Intra-Arterial therapy) trials suggest that its use may result in similar, if not better outcomes. ${ }^{7.8}$ Administration of thrombolytics requires intensive neurologic monitoring to document improvement and rule out symptomatic intracranial hemorrhage ( $\mathrm{sICH})$. Prompt delivery of the drug is essential as good outcomes decrease with increasing delays. The number-needed-to-treat (NTT) nearly doubles from five to nine at administration times within 90 minutes and 3 to 4.5 hours, respectively. ${ }^{9}$ American Heart Association (AHA) criteria for administration of IVrt-PA have been summarized in - Tables 1 and $2 .{ }^{4}$ An extensive list of contraindications must also be ruled out, in particular the presence of coexisting coagulopathies (platelet count $<100,000 / \mathrm{cc}$, international normalized ratio $[$ INR] $>1.7$, prothrombin time $>15$ seconds, activated partial thromboplastin time $>40$ seconds), possible sources of systemic hemorrhage, or recent trauma/surgery. ${ }^{4}$

The efficacy of IVT in achieving reperfusion in AIS with emergent large vessel occlusion (ELVO) is relatively suboptimal with $<30 \%$ success rates. ${ }^{10}$ This led to newer techniques of intra-arterial thrombolysis (IAT) initially and MT later.

Sonothrombolysis: Contemporaneous insonation of ultrasound using a transcranial Doppler probe augments the effect of clot-busting drugs. ${ }^{11}$ This effect may be further enhanced by the use of microbubble contrast media. The CLOTBUST (Combined Lysis of Thrombus in Brain Ischemia With Transcranial Ultrasound and Systemic tPA) and NOR-SASS (NORwegian Sonothrombolysis in Acute Stroke Study) trials showed a good safety profile but conflicting results regarding efficacy with a trend toward better outcomes over IVT alone in the former. ${ }^{12,13}$ However, outcomes have been inferior compared with MT. ${ }^{14}$ Sonothrombolysis is not recommended by the American Heart Association (AHA). ${ }^{4}$ Nonetheless, in a resource-poor environment such as ours, sonothrombolysis may be a viable and economical option helping improve outcomes. ${ }^{15}$ The CLOTBUST Hands-free

Table 1 Criteria for IV alteplase in AIS

\begin{tabular}{|c|c|}
\hline \multirow[t]{2}{*}{$<3 h$} & - Age: any > 18 y \\
\hline & $\begin{array}{l}\text { - Severity } \\
\text { - Disabling-any severity (severe, moderate, } \\
\text { mild) } \\
\text { - Nondisabling-mild (reasonable) }\end{array}$ \\
\hline \multirow[t]{4}{*}{$3-4.5 h$} & - Age: 18 to < $80 \mathrm{y}$ \\
\hline & $\begin{array}{l}\text { - Risk factors } \\
\text { - Not having both DM and prior stroke } \\
\text { - Not on OAC (unless INR < } 1.7 \text { ) }\end{array}$ \\
\hline & $\begin{array}{l}\text { - Nonsevere stroke i.e. } \\
\text { - NIHSS }<25 \\
\text { - }<1 / 3 \text { rd MCA territory }\end{array}$ \\
\hline & $\begin{array}{l}\text { - Vitals } \\
\text { - } \mathrm{BP}<180 / 110 \mathrm{~mm} \mathrm{Hg} \\
\text { - } \mathrm{RBS}>50 \mathrm{mg} / \mathrm{dL}, \text { but }<400 \mathrm{mg} / \mathrm{dL}\end{array}$ \\
\hline
\end{tabular}

Abbreviations: AIS, acute ischemic stroke; BP, blood pressure; DM, diabetes mellitus; INR, internation normalized ratio; IV, intravenous; MCA, middle cerebral artery; NIHSS, National Institutes of Health Stroke Scale; OAC, oral anticoagulation; RBS, random blood sugar. trial is currently an ongoing study that uses operator-independent insonation and may change current perspectives. ${ }^{16}$

Bridging therapy (BT): BT refers to the administration of IVT as an adjunct to MT in an eligible patient. The use of IVT + MT results in better functional outcomes increased recanalization rates with few number of device passes and reduced mortality with equivalent rates of sICH. ${ }^{17,18}$ However, controversy remains with some reporting nonsuperiority of BT over direct MT and increased mortality. ${ }^{19}$ Nonetheless, the AHA considers it a reasonable management strategy in-transit to a cath laboratory. However, waiting for clinical improvement post-IVT before considering MT (rescue BT) in an eligible patient has fallen out of practice and is no longer recommended. ${ }^{4}$

\section{Endovascular Treatment}

\section{Patient Selection and Decision Algorithm}

Patient selection is a nuanced cognitive process requiring consideration of multiple factors in stages to justify aggressive

Table 2 Technique and requirement of IVT administration

Dose: IV, $0.9 \mathrm{mg} / \mathrm{kg}$, max $90 \mathrm{mg} .10 \%$ as bolus over $1 \mathrm{~min}$, rest over $60 \mathrm{~min}$

(In Asians, $0.6 \mathrm{mg} / \mathrm{kg}$ was found to be noninferior)

\section{Monitoring}

- Requires ICU admission

- Monitoring: BP and neurologic examination

- $\mathrm{q} 15 \mathrm{~m} \times 2 \mathrm{~h} \rightarrow \mathrm{q} 30 \mathrm{~m} \times 6 \mathrm{~h} \rightarrow \mathrm{q} 1 \mathrm{~h} \times 24 \mathrm{~h}$

- Delay all tubes and catheter (NG, Foley's, arterial) insertions till completion of infusion

Red flags: Discontinue infusion if

- Severe headache

- Acute hypertension

- Nausea, vomiting

- Worsening neurologic deficits

If symptomatic ICH

- Resend CBC, coag profile, cross-match

- Emergent CT of head

- Cryoprecipitate $10 \mathrm{U}$ over $10-30 \mathrm{~min}$ (+10 U if fibrinogen $<200 \mathrm{~g} / \mathrm{dL}$ )

- Tranexamic acid (1,000 mg IV over $10 \mathrm{~min}$ ) or E-amino caproic acid 4-5 g IV over $1 \mathrm{~h}$ f/b $1 \mathrm{~g}$ IV till bleeding controlled

- Supportive therapy: BP, ICP, CPP, temperature, sugars

- Neurosurgery/hematology consults

If orolingual edema

- Treat as per AHA guidelines

Postinfusion imaging

- Repeat CT/MRI at $24 \mathrm{~h}$ for hemorrhage prior to initiating antiplatelet/coagulant therapy

Abbreviations: AHA, American Heart Association; CPP, cerebral perfusion pressure; $\mathrm{CT}$, computed tomography; $\mathrm{BP}$, blood pressure; $\mathrm{CBC}$, complete blood cell count; ICH, intracranial hemorrhage; ICU, intensive care unit; IV, intravenous; IVT, intravenous thrombolysis; MRI, magnetic resonance imaging; NG, nasogastric. 
invasive management. The first stage requires consideration of the patient's age, baseline functional status, and any comorbidities (and in our country, affordability) that are primary modifiers of the decision-making paradigm.

The next stage is to gather data on the degree of damage and decide whether the residue justifies endovascular treatment (EVT). Essentially two methods of patient selection are present: time- and perfusion-based. Central to both paradigms is the selection of a patient who has a relatively small core with ELVO and a significant salvageable penumbra. The AHA criteria for EVT are summarized in - Table 3. ${ }^{4}$

The management of a patient who presents $\leq 6$ hours is time based and requires only establishment of a disabling stroke but with a small core (clinical-radiologic mismatch) and ELVO. Treatment must be individualized in those with large core infarcts (discussed in the section on perfusion in part 1) and those with minimal symptoms (discussed below). Beyond 6 hours, the presence of a significant core/penumbra mismatch must be identified by perfusion imaging to justify EVT. An algorithm for imaging and management is presented in $\mathbf{- F i g}$. 1 .

Several prognostication scores are available that help predict outcomes of EVT ( - Table 4). ${ }^{20}$ Though most can predict poor outcomes, the PRE score is capable of predicting good outcomes as well. ${ }^{21}$ Only a few incorporate imaging characteristics suggesting that further work is required to create a more comprehensive score. ${ }^{20}$

The last stage is consideration of treatment options, their individual pros and cons with respect to patient comorbidities, vascular anatomy, and occlusion characteristics. It is important to remember to be flexible in the approach to patient selection with the knowledge that outcomes are a product of bayesian probability. ${ }^{22}$

\section{Technique of Endovascular Thrombectomy}

The procedure can be divided into three phases: preprocedure, diagnostic-access, and intervention phases.

\section{Preprocedure Phase}

Rapid transit to a cath laboratory is necessary. The ESCAPE and SWIFT-PRIME (Solitaire with the Intention for Thrombectomy as Primary Endovascular Treatment for Acute Ischemic Stroke) trials recommend a time period of $<60$ minutes and $<70$ minutes (maximum 90 minutes). ${ }^{23,24}$ Advance activation of the neurointervention team is necessary.

Patient preparation: Unlike a traditional elective neurointervention case, time is of the essence. A simple electric shaver will do for groin preparation. Foley's catheterization is an unnecessary delay. Ensure a large-bore IV line is inserted. Maintain blood pressures (BP) using nonglucose crystalloids to avoid hyperglycemia.

Anesthesia: The potential advantages of general anesthesia (GA) cannot be ignored. Patient movement whether related to pain or altered sensorium is disruptive to the procedure. Groin puncture and stentriever retrieval can cause pain. Airway aspiration is also an ever-present danger. Apart from analgesia, GA can streamline the interventional procedure, improving recanalization times and reducing fluoroscopy times. ${ }^{25} \mathrm{GA}$, however, does not allow neurologic examination during and immediately postprocedure. Further, it results in poorer chances of a good functional outcome, increased hospital stay post revascularization, and a higher case fatality rate. ${ }^{26,27}$ These differences remained despite accounting for the likelihood that patients with more severe strokes were

Table 3 AHA eligibility criteria for MT in AIS with ELVO

\begin{tabular}{|c|c|}
\hline Age & $\begin{array}{l}\text { - Definite indication } \\
\text { - } \geq 18 \mathrm{y} \\
\text { - Reasonable indication but uncer- } \\
\text { tain benefit } \\
\text { - } \geq 90 \mathrm{y}-\text { consider life expectan- } \\
\text { cy, quality of life, etc. }\end{array}$ \\
\hline Prestroke mRS & $\begin{array}{l}\text { - Definite indication } \\
\text { - } 0-1 \\
\text { Reasonable indication but uncer- } \\
\text { tain benefit } \\
->1\end{array}$ \\
\hline NIHSS & $\begin{array}{l}\text { - Definite indication } \\
\cdot \geq 6 \text { and }<25 \\
\text { - Reasonable indication but uncer- } \\
\text { tain benefit } \\
\text { - }<6 \text { (i.e., stroke with minimal } \\
\text { symptoms) and ICA or M1 ELVO }\end{array}$ \\
\hline ASPECTS & $\mathrm{CT} \geq 6($ if $\mathrm{DWI} \geq 5)$ \\
\hline ELVO & $\begin{array}{l}\text { - Definite indication } \\
\text { - ICA, M1 MCA } \\
\text { - Reasonable indication but uncer- } \\
\text { tain benefit } \\
\text { - } \mathrm{M} 2 / \mathrm{M} 3 \mathrm{MCA} \\
\text { - ACA } \\
\text { - VA, BA, PCA }\end{array}$ \\
\hline $\begin{array}{l}\text { Ictus to groin } \\
\text { puncture time }\end{array}$ & $\begin{array}{l}\text { - } \leq 6 \mathrm{~h} \text {-indicated if above criteria } \\
\text { satisfied } \\
\text { - 6-16 h-indicated if ELVO and } \\
\text { DAWN or DEFUSE } 3 \text { criteria } \\
\text { satisfied } \\
\text { ○ DAWN criteria } \\
\text { - Age } \leq 80 \mathrm{y} \text { : NIHSS } \geq 10 \text {, } \\
\text { infarct volume }<31 \mathrm{cc} \\
\text { - Age }>80 \mathrm{y} \text { : NIHSS } \geq 10, \\
\text { infarct volume }<21 \mathrm{cc} \\
\text { - Infarct volume }<70 \mathrm{cc} \\
\text { - Ischemic tissue-to-core } \\
\text { ratio }>1.8 \\
\text { 6-24 h-indicated if ELVO }+ \\
\text { DAWN eligibility criteria satisfied }\end{array}$ \\
\hline
\end{tabular}

Abbreviations: ACA, anterior cerebral artery; AHA, American Heart Association; AIS, acute ischemic stroke; ASPECTS, Alberta Stroke Program Early CT Score; BA, basilar artery; CT, computed tomography; DAWN, Diffusion Weighted Imaging (DWI) or Computerized Tomography Perfusion (CTP) Assessment With Clinical Mismatch in the Triage of Wake Up and Late Presenting Strokes Undergoing Neurointervention; DEFUSE, Diffusion and Perfusion Imaging Evaluation for Understanding Stroke Evolution; DWI, diffusion-weighted imaging; ELVO, emergent large vessel occlusion; ICA, internal carotid artery; MCA, middle cerebral artery; mRS, modified Rankin scale; MT, mechanical thrombectomy; NIHSS, National Institutes of Health Stroke Scale; VA, vertebral artery. 


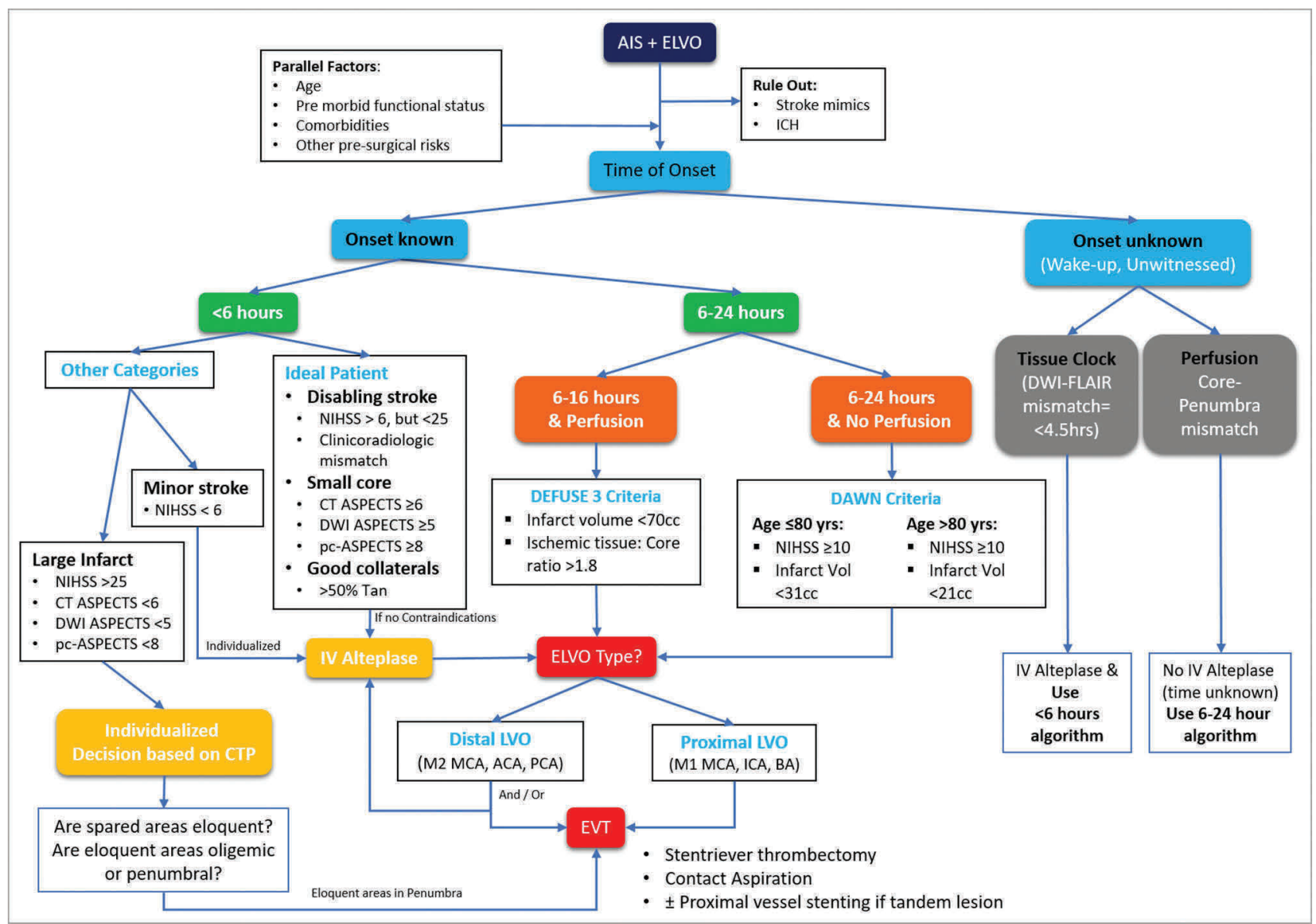

Fig. 1 Suggested algorithm for imaging and patient management in acute ischemic stroke (AIS). ACA, anterior cerebral artery; ASPECTS, Alberta Stroke Program Early CT Score; CT, computed tomography; DWI, diffusion-weighted imaging; ELVO, emergent large vessel occlusion; FLAIR, fluid-attenuated inversion recovery; ICH, intracranial hemorrhage; IV, intravenous; MCA, middle cerebral artery; NIHSS, National Institutes of Health Stroke Scale; PCA, posterior cerebral artery; pc-ASPECTS, posterior circulation ASPECTS.

more likely to be intubated. One likely cause is transient patient hypotension during induction that can compromise already failing cerebral circulation. ${ }^{28}$ Delays during induction may be another reason. ${ }^{28}$ However, an experienced anesthesiologist, rapid induction techniques, and strict maintenance of normotension and normocarbia can produce equivalent outcomes as was shown in the SIESTA (Sedation vs. Intubation for Endovascular Stroke TreAtment) trial. ${ }^{29,30}$ At present time, conscious sedation is the standard of care, and GA is preferred in neurologically or hemodynamically unstable patients, excessively uncooperative patients, or those with compromised airway protective reflexes.

\section{Diagnostic-Access Phase}

Diagnostic angiography: Obtain femoral arterial access and secure a 5 to 7F short sheath initially, which will need to be switched to an $8 \mathrm{~F}$ sheath later on. Heparin may be given as for any intervention, usually 3,000 to 5,000 IU. ${ }^{31}$ Use a diagnostic catheter (vertebral, right coronary or Simmons) to navigate into the ipsilateral internal carotid artery (ICA) and obtain a diagnostic cerebral angiogram. Angiograms of the contralateral ICA or vertebral artery (VA) are unnecessary and may be obtained only if neck vessel occlusion is present. Assess level of occlusion using bony landmarks and degree of collaterals visually. It is important to formally assign a baseline modified thrombolysis in cerebral infarction (TICI) score (- Table 5) and grade collateral status using the Higashida scheme postprocedure (-Table 6).

Access phase: Use an exchange length 0.035 in Terumo Glidewire (Terumo Interventional Systems) or an extrastiff Amplatz wire (Boston Scientific, Cook Medical) to exchange a guide catheter into the cervical vessels. Choice of a guide catheter is dependent on the MT technique and is discussed as follows. Consider using a long sheath or Neuron Max (Penumbra Inc.) if significant vascular tortuosity.

\section{Intervention Phase}

Intra-arterial thrombolysis: IAT is now considered obsolete. The ProACT (Procalcitonin Antibiotic Consensus Trial) trials did show a significantly higher rate of good functional outcome ( $40 \%$ vs. $25 \%$ ) in patients achieving recanalization (66\% vs. $18 \%$ ) with IA pro-urokinase and heparin than IVT alone but with a much higher rate of $\mathrm{sICH}(10 \% \text { vs. } 2 \%)^{32}$ A confirmatory trial was never performed, and FDA approval was never given. This technique was thus superseded by other more effective techniques ( - Table 7 ). 
Stentriever MT: Stentrievers are the current standard of care. Thrombectomy devices underwent three generations of evolution:

- The first-generation devices were the Merci retriever devices (Concentric Medical/Stryker, Inc.). These consisted of a

Table 4 Prognostic scores for EVT

\begin{tabular}{|c|c|c|}
\hline $\begin{array}{l}\text { PRE } \\
\text { Pittsburgh Re- } \\
\text { sponse to Endo- } \\
\text { vascular therapy }\end{array}$ & $\begin{array}{l}\text { Age }+2(\text { NIHSS }-10) \times \\
\text { ASPECTS }\end{array}$ & $\begin{array}{l}-25 \text { to } \\
+49= \\
\text { High } \\
\text { likeli- } \\
\text { hood of } \\
\text { benefit } \\
\geq 50 \\
=\text { Not } \\
\text { likely to } \\
\text { benefit }\end{array}$ \\
\hline $\begin{array}{l}\text { SPAN } \\
\text { Stroke Prognosti- } \\
\text { cation using Age } \\
\text { and NIHSS }\end{array}$ & Age + NIHSS & $\begin{array}{l}\geq 100 \\
\text { poor } \\
\text { out- } \\
\text { comes, } \\
\text { high risk }\end{array}$ \\
\hline $\begin{array}{l}\text { THRIVE } \\
\text { Totaled Health } \\
\text { Risks in Vascular } \\
\text { Events }\end{array}$ & 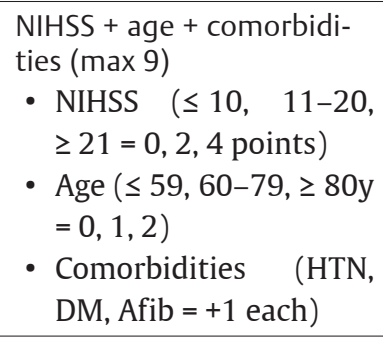 & $\begin{array}{l}6-9= \\
\text { poor } \\
\text { outcome }\end{array}$ \\
\hline $\begin{array}{l}\text { HIAT } \\
\text { Houston Intra- } \\
\text { Arterial Iherapy }\end{array}$ & $\begin{array}{l}\text { Age }+ \text { NIHSS + glucose } \\
(\max 3) \\
- \text { Age }>75 \mathrm{y}=1 \\
\text { - NIHSS }>18 \\
\text { - Glucose }>150 \mathrm{mg} / \mathrm{dL}=1\end{array}$ & $\begin{array}{l}\geq 2= \\
\text { poor } \\
\text { out- } \\
\text { comes }\end{array}$ \\
\hline $\begin{array}{l}\text { HIAT } 2 \\
\text { Houston Intra- } \\
\text { Arrterial Iherapy } \underline{2}\end{array}$ & $\begin{array}{l}\text { Age + NIHSS + glucose } \\
(\max 8) \\
-\quad \text { Age }(\leq 59,60-79, \geq 80 \\
\quad y=0,2,4) \\
-\quad \text { Glucose }(<150, \geq 150 \\
\text { mg/dL }=0,1) \\
\text { - NIHSS }(\leq 10,>10=0,1)\end{array}$ & $\begin{array}{l}\geq 5= \\
\text { poor } \\
\text { outcome }\end{array}$ \\
\hline $\begin{array}{l}\text { SAD } \\
\text { Stanford Age and } \\
\text { Diffusion-weight- } \\
\text { ed imaging }\end{array}$ & $\begin{array}{l}\text { Age + DWI volume } \\
\text { - Age }(\leq 55,56-69,70-79 \text {, } \\
\geq 80 \mathrm{y}=0,1,2,3) \\
\text { - DWI volume }(\leq 15 \mathrm{~mL},> \\
15 \mathrm{~mL}=0,1)\end{array}$ & \\
\hline 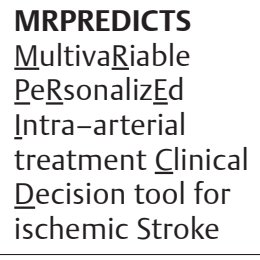 & $\begin{array}{l}\text { http://mrpredicts.shin- } \\
\text { yapps.io/RRRR/ }\end{array}$ & \\
\hline $\begin{array}{l}\text { iSCORE } \\
\text { Ischemic Stroke } \\
\text { predictive Risk }\end{array}$ & $\begin{array}{l}\text { http://www.sorcan.ca/ } \\
\text { iscore/ }\end{array}$ & \\
\hline
\end{tabular}

Abbreviations: ASPECTS, Alberta Stroke Program Early CT Score; DM, diabetes mellitus; HTN, hypertension; DWI, diffusion-weighted imaging; EVT, endovascular treatment; NIHSS, National Institutes of Health Stroke Scale. nitinol based coil that was delivered through a microcatheter into the clot. There were three iterations of the devices themselves: the $\mathrm{X}$ series (with a corkscrew appearance of coil), $\mathrm{L}$ series (nontapering coil bent at 90 degrees with arcading filaments), and the $\mathrm{V}$ series (a hybrid version with nontapering coil and arcading filaments provided in soft and firm versions). ${ }^{33}$ The MERCI (Mechanical Embolus Removal in Cerebral Ischemia) and Multi-MERCI trials showed a higher rate of recanalization and good outcomes but with higher mortality rates compared with historical controls. These had a high rate of nontarget embolization (NTE) ${ }^{34,35}$ Nonetheless, they paved the way for future trials and devices.

- The second-generation device was the Penumbra aspiration system (Penumbra, Inc.) consisting of a reperfusion catheter with a separator. These were available in four sizes (with internal diameters [IDs] of 0.054-0.026 in) with a corresponding sized separator for occlusions from the ICA to the M2 middle cerebral artery (MCA). The aim was to size the catheter to the artery without causing wedging so as to efficiently aspirate the thrombus. A proprietary aspiration pump was used to generate a continuous negative suction of up to $20 \mathrm{~mm} \mathrm{Hg}$ with the separator moved back and forth to clear the ingested clot. ${ }^{36}$ The Penumbra Pivotal trial was a nonrandomized trial to establish the efficacy and safety of the devices. Despite high recanalization rates (82\%), good clinical outcomes remained poor (only $25 \%$ ) with high complication rates of $12.8 \%{ }^{37}$

- The third-generation devices were the stentrievers ( - Table 8, - Fig. 2) consisting of a retrievable stent. They were initially used to only act as a temporary bypass across the thrombus to allow IAT. Only later were

Table 5 mTICl score

\begin{tabular}{|l|l|l|l|}
\hline Grade & $\begin{array}{l}\text { Antegrade } \\
\text { flow }\end{array}$ & $\begin{array}{l}\text { Tissue } \\
\text { reperfusion }\end{array}$ & $\begin{array}{l}\text { Original TICI } \\
\text { grade }\end{array}$ \\
\hline 0 & Nil & Nil & Same \\
\hline 1 & Present & Nil & Same \\
\hline 2A & Present & Partial $<50 \%$ & Partial <66\%\% \\
\hline 2B & Present & Partial 50-99\% & Partial 66-99\% \\
\hline 3 & Present & Complete 100\% & Complete $100 \%$ \\
\hline
\end{tabular}

Abbreviations: $\mathrm{mTICl}$, Modified thrombolysis in cerebral Infarction.

Table 6 ASITN/SIR collateral vessel grading system (by Higashida et al)

\begin{tabular}{|l|l|l|l|}
\hline Grade & $\begin{array}{l}\text { Ischemic site } \\
\text { filling }\end{array}$ & $\begin{array}{l}\text { Speed of } \\
\text { retrograde flow }\end{array}$ & $\begin{array}{l}\text { Perfusion } \\
\text { deficit }\end{array}$ \\
\hline 1 & No & - & $\begin{array}{l}\text { Whole } \\
\text { territory }\end{array}$ \\
\hline 2 & Till periphery & Slow & Partial \\
\hline 3 & Till periphery & Rapid & Partial \\
\hline 4 & Complete & Slow & Nil \\
\hline 5 & Complete & Rapid & Nil \\
\hline
\end{tabular}

Abbreviations: ASITN, American Society of Interventional and Therapeutic Neuroradiology; SIR, Society of Interventional Radiology. 
they used directly for MT. The first of these were the Solitaire-AB (ev3/Medtronic) and Trevo (Stryker, Inc.) devices whose safety and efficacy were first established by the SWIFT and TREVO 2 trials. These devices were the reason for the success of the six recent landmark

Table 7 EVT techniques

\begin{tabular}{|l|l|}
\hline $\begin{array}{l}\text { EVT } \\
\text { technique }\end{array}$ & Remarks \\
\hline $\begin{array}{l}\text { Me- } \\
\text { chanical } \\
\text { throm- } \\
\text { bectomy }\end{array}$ & $\begin{array}{l}\text { Stentriever-based enmeshment of clot } \\
\text { (previously Merci) }\end{array}$ \\
\hline $\begin{array}{l}\text { Distal As- } \\
\text { piration } \\
\text { throm- } \\
\text { bectomy }\end{array}$ & $\begin{array}{l}\text { FAST (manual aspiration using older Penumbra } \\
\text { system) } \\
\text { ADAPT (newer direct large-bore catheter aspi- } \\
\text { ration without BGC) }\end{array}$ \\
\hline $\begin{array}{l}\text { Solumbra } \\
\text { Combination of retrieval device (Solitaire) and } \\
\text { aspiration catheter (Penumbra) }\end{array}$ \\
\hline $\begin{array}{l}\text { PROTECT } \\
\text { PROTECT aspiration during stent retriever } \\
\text { thrombectomy-combination of BGC, aspira- } \\
\text { tion catheter, and stentriever }\end{array}$ \\
\hline $\begin{array}{l}\text { Distal } \\
\text { embo- } \\
\text { lization } \\
\text { protec- } \\
\text { tion }\end{array}$ & $\begin{array}{l}\text { Lazarus effect cover for stentriever } \\
\text { thrombectomy }\end{array}$ \\
\hline
\end{tabular}

Abbreviations: ADAPT, A Direct Aspiration first Pass Thrombectomy; BGC, Balloon guide catheter; EVT, endovascular treatment; FAST, Forced Aspiration Suction Thrombectomy; PROTECT, PRoximal balloon Occlusion TogEther with direCt Thrombus. trials being used in more than $80 \%$ of patients. ${ }^{23,24,38-41}$ MT with third-generation stentrievers is the recommended treatment for ELVO achieving reperfusion (TICI $2 \mathrm{~b} / 3$ ) in 59 to $88 \%$ of cases. ${ }^{42}$

The technique of stentriever delivery first requires blindly crossing the occlusion with a microwire-microcatheter combination. A microcatheter angiogram is necessary to ensure correct intraluminal position and evaluation of distal flow patterns. ${ }^{43}$ The microwire is exchanged for the stentriever that is then deployed across the thrombus by pulling back the microcatheter like a sleeve (unsheathing technique). For closed cell devices such as Trevo, pushing in the stentriever into the clot during deployment (the push and fluff technique) causes foreshortening and increases radial force resulting in better clot integration. ${ }^{44}$ Longer stentrievers result in better outcomes. ${ }^{45}$ The stentrievers are deployed for a few minutes (usually 5 minutes) for integration of the clot into the struts ( - Fig. 3). An increased dwell time ( $\sim 8$ minutes) allows for superior clot embedment and higher rates of recanalization with a single pass. ${ }^{46}$ This is likely related to the shape memory effect of nitinol. ${ }^{47}$ During clot retrieval, the microcatheter is minimally advanced onto the detachment zone of the stentriever, and the entire stentriever-microcatheter assembly is pulled back as a unit. Aspiration needs to be applied to the guide catheter throughout this retrieval process, to prevent NTE. Though there is no agreed-upon limit for the maximum number of passes, five passes may be reasonable before considering the procedure a failure. ${ }^{48}$ The aim is to achieve

Table 8 Types of stentrievers

\begin{tabular}{|c|c|c|}
\hline Stentriever & Company & Remarks \\
\hline Solitaire FR, AB, 2 & Medtronic & $\begin{array}{l}\text { Overlapping stent design } \\
\text { Detachable electrolytic (AB), nondetachable (FR, 2) }\end{array}$ \\
\hline Mindframe Capture LP & Medtronic & Low profile, delivery through 0.017 -in microcatheter, for distal occlusions \\
\hline $\begin{array}{l}\text { Trevo ProVue, XP Provue, } \\
\text { Baby Trevo }\end{array}$ & Stryker & Fully visible struts, Baby Trevo for use in distal occlusions \\
\hline pREset, pREset Lite & Phenox & $\begin{array}{l}\text { Helical slit design allows increase radial force } \\
\text { Proximal ring design allows complete opening even in curves } \\
\text { Small profile- } 0.021 \text { in (standard) and } 0.0165 \text { in (Lite) microcatheter compatible }\end{array}$ \\
\hline $3 \mathrm{D}$ revascularization device & Penumbra & $\begin{array}{l}\text { Unique design minimizes vessel contact } \\
\text { Meant for use with ADAPT }\end{array}$ \\
\hline Eric & Microvention & $\begin{array}{l}\text { ERIC } \\
\text { Series of interlinked adjustable nitinol cages with high metal coverage-allows } \\
\text { for faster thrombus capture, integration, and withdrawal }\end{array}$ \\
\hline ReVive SE & Codman & Closed end basket reduced NTE \\
\hline Aperio & Acandis & $\begin{array}{l}\text { Hybrid cell design: Smaller cells for apposition; larger cells allow integration of } \\
\text { clot, small profile- } 0.021 \text { in microcatheter compatible }\end{array}$ \\
\hline $\begin{array}{l}\text { Catch Plus (Standard, Mini, } \\
\text { Maxi, Mega) }\end{array}$ & Balt & $\begin{array}{l}\text { Wide range of device sizes; can be delivered through } 0.017 \text { in microcatheter } \\
\text { (mini) to } 0.040 \text { in (mega) }\end{array}$ \\
\hline Tigertriever & Rapid Medical & Adjustable diameter with handle \\
\hline $\begin{array}{l}\text { Neuravi EmboTrap II revas- } \\
\text { cularization device }\end{array}$ & Neuravi & $\begin{array}{l}\text { Dual-stent design-inner stent mesh has high radial force that creates consistent } \\
\text { central revascularization channel; outer stent mesh has lower radial force that } \\
\text { allows clot embedment }\end{array}$ \\
\hline Golden retriever & $\begin{array}{l}\text { Amnis Thera- } \\
\text { peutics }\end{array}$ & $\begin{array}{l}\text { Thinnest stentriever; passes through clot like a wire when collapsed; consists of } 5 \\
\text { crown elements that can be opened up for retrieval }\end{array}$ \\
\hline
\end{tabular}

Abbreviations: ADAPT, A Direct Aspiration first Pass Thrombectomy; ERIC, Embolus Retrieval with Interlinked Cages; NTE, nontarget embolization. 


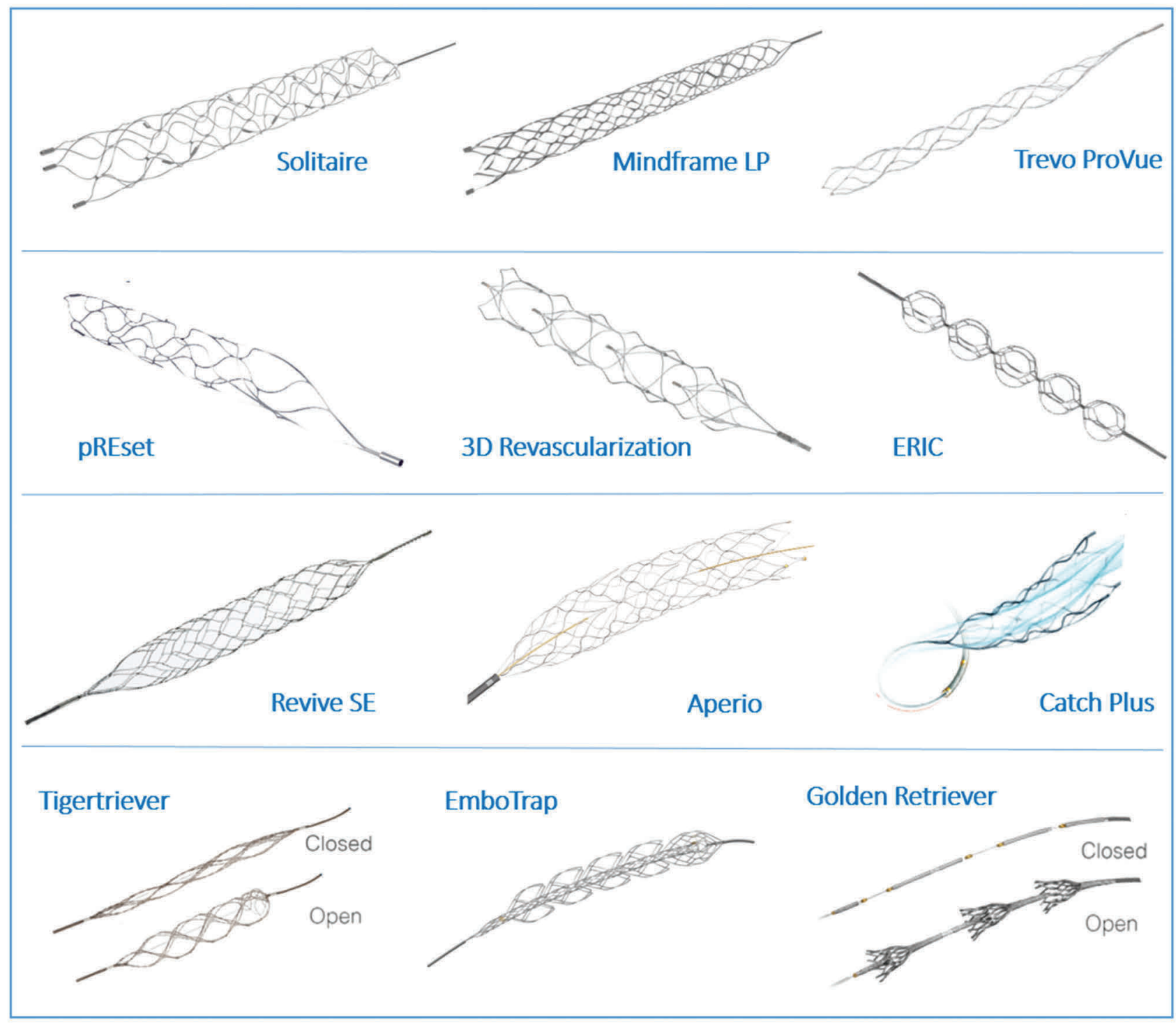

Fig. 2 Different designs of stentrievers.

recanalization within 60 minutes in at least $70 \%$ of patients with the caveat that the complication rate increases with the number of passes. ${ }^{49}$

The guide catheter system, usually large bore (8-9F), can have an impact on the safety and efficiency of aspiration. Three options exist: conventional (CGC), and balloon guide catheters (BGCs), and distal access catheters (DAC). ${ }^{50}$ The advantage of BGCs over CGC is that they allow flow arrest permitting more efficient aspiration and reduced rates of NTE (10-12\% vs. 53\% with BGC). ${ }^{51}$ An exchange method or coaxial advancement technique is used to place the GC. The tip is usually parked at the ICA bulb or V1/V2 segments. ${ }^{50}$ CGCs such as Neuron or Envoy are more practical in the posterior circulation. DACs require a triaxial system and are of use in more distal occlusions or tortuous vasculature. They are parked as close to the occlusion as possible to reduce the retrieval corridor and thrombus dispersion. The efficiency of aspiration is, however, reduced due to their narrower lumens. ${ }^{52}$

Aspiration thrombectomy (AT): Also known as the contact aspiration technique, AT was originally used with the
Penumbra aspiration pump system (PS) in combination with a separator to break up the clot. Concurrent with the rise of stentrievers, refinements in AT continued. The forced aspiration thrombectomy (FAST) technique was the first of these and was used as a bailout procedure when revascularization failed with the PS separator. ${ }^{53}$ Manual aspiration with a 20/50 cc syringe was done through the reperfusion catheter without the separator. This resulted in an improved rate of recanalizations over the original PS technique. ${ }^{53}$

A direct aspiration first-pass technique (ADAPT) completely did away with the use of a separator and depended solely on the aspiration force of a pump to remove the clot. The technique uses the newer-generation, more flexible, atraumatic large-bore, coil-reinforced catheters ( - Table 9, - Fig. 4) whose larger lumens allow a larger surface area of contact with the clot and increase aspiration capacity. ${ }^{54}$ Two modes of clot retrieval are possible: if the clot is disrupted, blood flows into the pump canister (disrupted clot type), whereas lack of flow into the canister means that the intact clot is wedged at the tip (whole clot type). ${ }^{53}$ Because crossing the occlusion is 


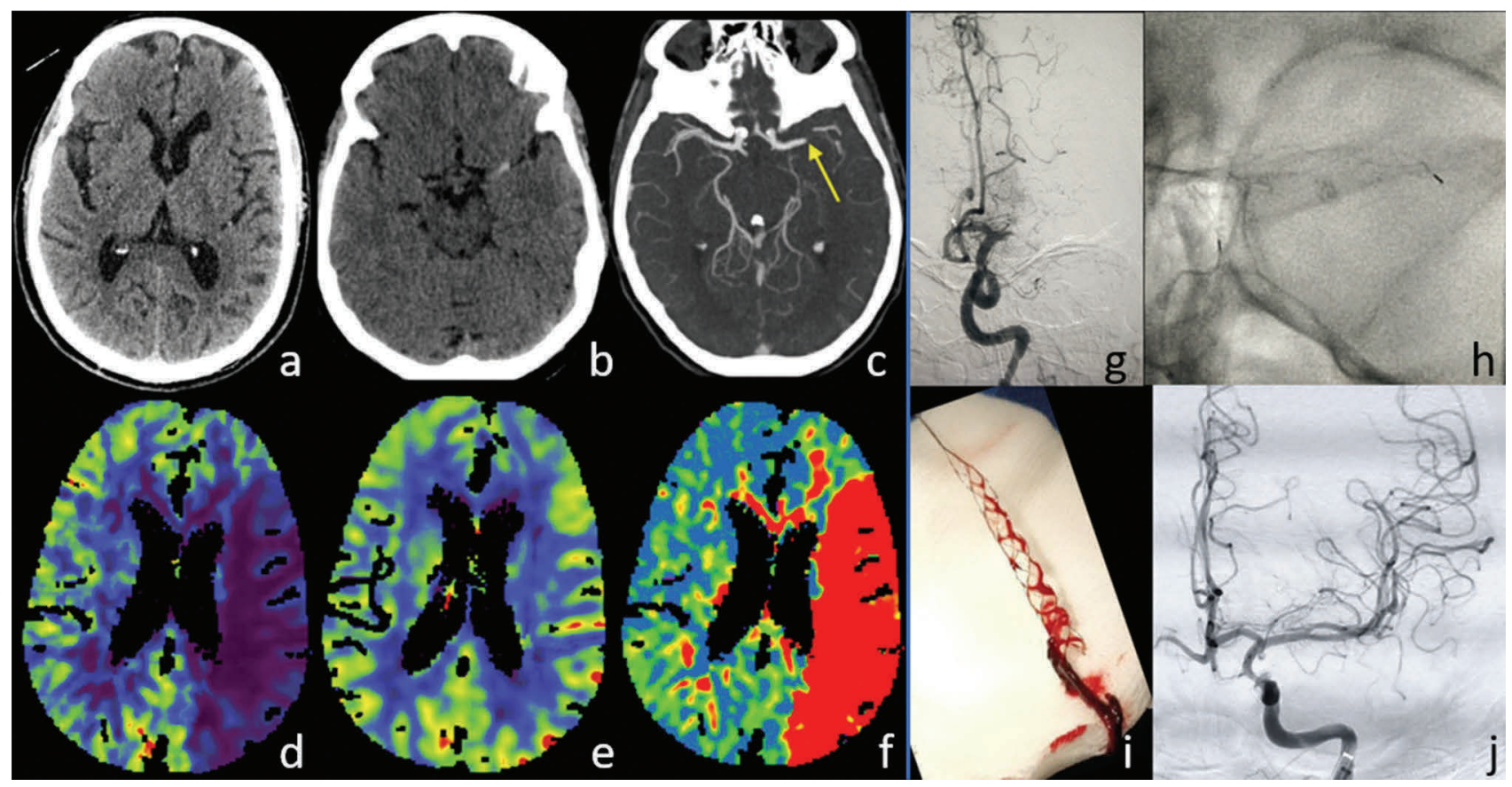

Fig. 3 Illustrative case:A 56-year-old man presented with AIS features localizing to the left cerebral hemisphere (NIHSS 19) within 2 hours of ictus. Plain CT showed no definite early ischemic changes (a) but a dense MCA sign (b). A CT perfusion was performed. (d) MTT, (e) CBV, and (f) CBF maps showed no significant core with a large penumbra. (c, arrow) CTA confirmed an occlusion of the left M1 MCA and > 50\% collaterals. (g) Initial DSA showed cutoff of the left MCA. (h) A Solitaire stentriever was deployed across the occlusion with retrieval of clot in first attempt (i). (j) Check angiogram showed $\mathrm{TICl}$ grade 3 recanalization.

no longer necessary, rates of NTE and hemorrhage associated with superselective angiography are reduced..$^{55}$ This also reduces recanalization times (sometimes just 4.5 minutes from puncture). ${ }^{56}$ Indeed, early recanalization ( $<35$ minutes) results in more complete revascularization and better clinical outcomes. ${ }^{57}$ Further, the procedure is versatile, allowing easy bailout with stentriever techniques (usually after three failed attempts). With comparable rates of successful reperfusion (78\% in the ADAPT-FAST trial, improving to $95 \%$ with stentriever bailout), AT has challenged the monopoly of stentriever techniques. ${ }^{55}$ The ASTER (Contact Aspiration Versus Stent Retriever for Successful Revascularization) trial, however, showed mixed results with poorer 90-day clinical outcomes (45.3\% in AT vs. $50 \%$ in MT) despite better rates of recanalization (85.4\% vs. $83.1 \%$ respectively)..$^{58}$ Stentrievers thus are the preferred option in the AHA guidelines, although use of the ADAPT technique remains reasonable. ${ }^{4}$

Switching/bailout technique: For switching from stentriever thrombectomy to aspiration, two possible options are available. The first option involves removal of the microcatheter-stentriever combination completely and then introducing the aspiration catheter as usual similar to primary ADAPT. The second option is to remove only the stentriever leaving the microcatheter in place. The next step is to pass the microwire with a docking wire and use this to exchange the aspiration system directly into place. This latter option is particularly useful if navigation was difficult. For switching from aspiration to stentriever thrombectomy, an additional microcatheter wire is navigated through the indwelling aspiration catheter for subsequent delivery of the stentriever.
Table 9 Types of aspiration catheters

\begin{tabular}{|c|c|c|}
\hline $\begin{array}{l}\text { Aspiration } \\
\text { catheter }\end{array}$ & Company & Remarks \\
\hline $\begin{array}{l}\text { Ace } 3,4,5 \\
\text { Max }\end{array}$ & Penumbra & $\begin{array}{l}\text { 2nd-generation aspiration } \\
\text { catheters } \\
3,4 \text { Max still useful for distal } \\
\text { occlusion of M2 MCAs or for co- } \\
\text { axial delivery of larger aspiration } \\
\text { catheters }\end{array}$ \\
\hline $\begin{array}{l}\text { Ace } 60 \\
64,68\end{array}$ & Penumbra & $\begin{array}{l}\text { Latest 3rd-generation aspiration } \\
\text { catheters, more flexible, better } \\
\text { support, high-flow aspiration-to } \\
\text { replace Ace } 5 \text { Max. } \\
\text { Sizing to fit OD into vessel diame- } \\
\text { ter, number represents ID. } \\
\text { Ace } 60 \text { for distal M1, Ace } 64,68 \\
\text { for proximal M1 and ICA }\end{array}$ \\
\hline $\begin{array}{l}\text { Sofia, } \\
\text { Sofia Plus } \\
\text { Distal } \\
\text { Access } \\
\text { Catheter }\end{array}$ & $\begin{array}{l}\text { Microven- } \\
\text { tion }\end{array}$ & $\begin{array}{l}\text { Soft torqueable catheter, op- } \\
\text { timized for intracranial access, } \\
\text { distal IDs of } 0.068 \text { and } 0.70 \text { (plus) }\end{array}$ \\
\hline $\begin{array}{l}\text { Arc, Arc } \\
\text { Mini In- } \\
\text { tracranial } \\
\text { Support } \\
\text { catheter }\end{array}$ & Medtronic & Distal ID of 0.061 in \\
\hline $\begin{array}{l}\text { Catalyst } \\
\text { (Cat 6) }\end{array}$ & Stryker & $\begin{array}{l}\text { Distal ID of } 0.060 \text { in, claims } 3 x \\
\text { more trackability than Ace } 64 \text {. }\end{array}$ \\
\hline Revive IC & Cordis & Distal ID of 0.056 in \\
\hline
\end{tabular}

Abbreviations: ACA, anterior cerebral artery; ID, inner diameter; MCA, middle cerebral artery; OD, outer diameter. 


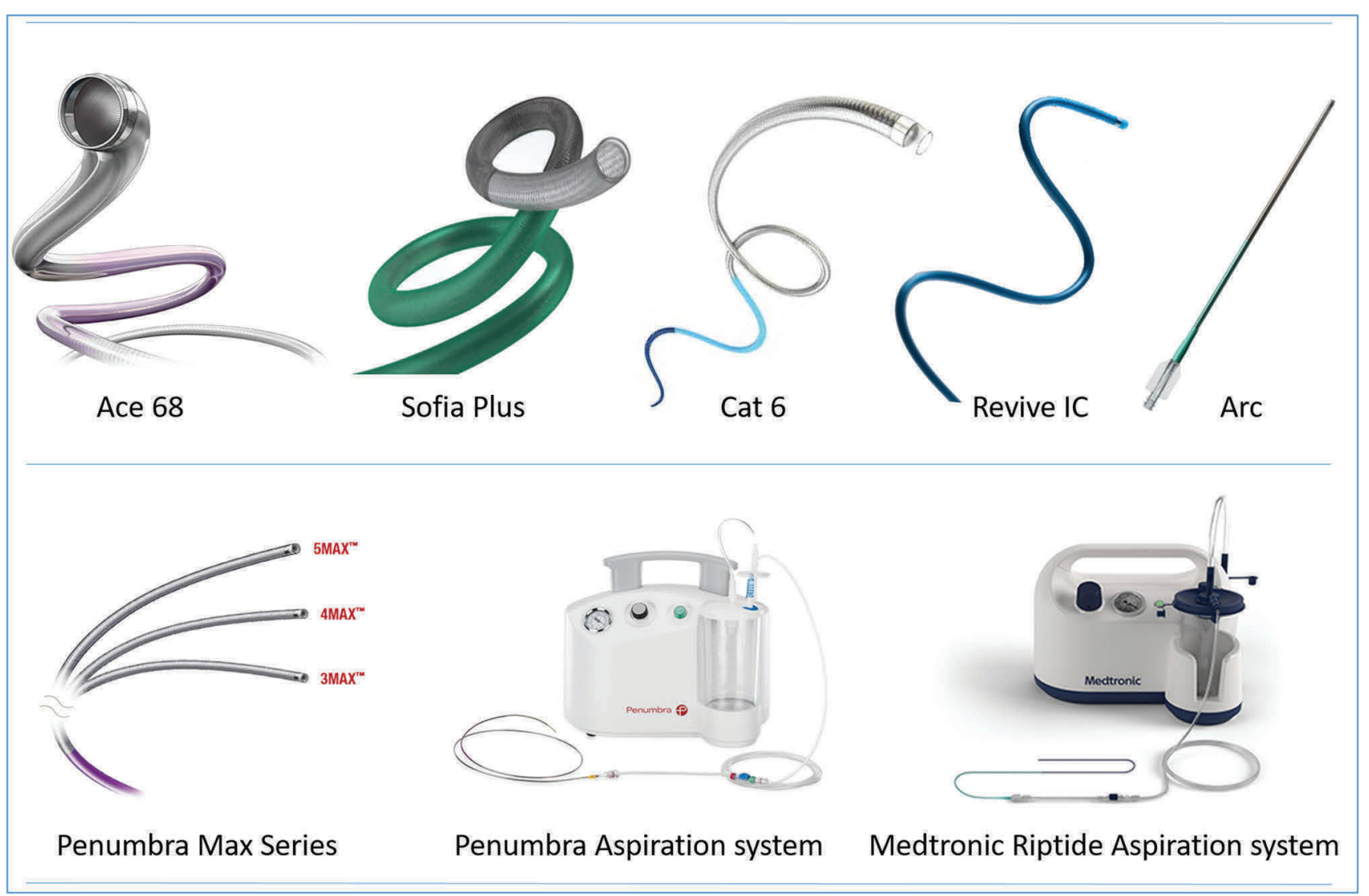

Fig. 4 Different types of aspiration catheters and pumps.

Solumbra technique: The awareness that the bailout use of stentrievers with AT improved recanalization rates, a technique of primary combined use of both techniques together was devised. ${ }^{58,59}$ The procedure used a triaxial system consisting of a GC, a Penumbra catheter, and a Solitaire stentriever, and was aptly named the Solumbra technique. Improved support for stentriever retrieval with aspiration achieved good recanalization rates of $88 \% .^{59}$ However, its efficacy remains controversial as it performed inferior to the ADAPT technique in a comparative case series. ${ }^{60}$

PROTECT technique: PRoximal balloon Occlusion TogEther with direCt Thrombus aspiration during stent retriever thrombectomy (PROTECT) is an advancement of the Solumbra technique that uses a BGC. ${ }^{61}$ The addition of a BGC has two advantages: it causes complete flow arrest preventing NTE and simultaneously improves efficacy of distal aspiration. As a result, PROTECT resulted in improved procedure times ( 29 vs. 40 minutes in Solumbra) and a higher rate of reperfusion (70 vs. $39 \%$ respectively) in a comparative case series. ${ }^{62}$ This technique is known by multiple other acronyms leading to confusion in literature. ${ }^{63}$

Lazarus effect cover-assisted MT: This is a distal embolization protection device for stentriever thrombectomy. It consists of a funnel-shaped nitinol mesh designed to surround the stentriever and the enmeshed thrombus during retrieval..$^{64}$ Following stentriever deployment, the Lazarus device is positioned at its proximal end. Retraction of the stentriever against the device causes it to invert and roll over the outside of the stentriever. This protective sheath prevents clot fragmentation and distal embolization. It has also been used with distal aspiration techniques. ${ }^{65}$

Assessing revascularization: Recanalization should be achieved as rapidly as possible, preferably within the therapeutic window. ${ }^{4}$ Histopathologic and microbiological examination of the retrieved thrombi may aid in the etiologic workup and help retrospectively correlate any procedural difficulties with the type of thrombus. ${ }^{66,67}$ Some studies have suggested a possible correlation between stroke etiology, thrombus composition, and angiographic outcomes. ${ }^{68-70}$ However, a recent systematic review found no significant association between stroke etiology and clot composition. ${ }^{71}$ Regardless of etiology, however, a higher rate of recanalization was found for red blood cell (RBC)-rich thrombi as opposed to white blood cell (WBC)-rich thrombi. ${ }^{71}$ The hyperdense artery sign, an imaging marker of such RBC-rich thrombi, thus simultaneously predicts poor response to IVT and better outcomes post-EVT. ${ }^{71,72}$ More studies are required in this field.

Multiple reperfusion scales such as the Qureshi scale, Mori reperfusion scale, and the Arterial Lesion Occlusion score exist. However, the modified TICI score is most commonly used to assess the degree of recanalization and reperfusion (-Table 5). ${ }^{73-76} \mathrm{~A}$ good revascularization outcome is classified as TICI $2 \mathrm{~b}$ or 3 ; however, differences remain even between these two grades. TICI 3 patients are more likely to reach a good functional outcome (71.7\% vs. $50.5 \%)$ and lower 
rates of ICH (23\% vs. $45 \%$ ) when compared with TICI 2 b. ${ }^{77}$ The brain is thus an unforgiving territory, and excellent outcomes must be aimed for. A further refinement of the mTICI score introduced 2c with 90 to $100 \%$ recanalization, but this is as yet to be validated. ${ }^{49}$

\section{Special Situations}

Intracranial atherosclerosis-related occlusions (ICAS-0): Most revascularization therapies have been directed predominantly toward embolic occlusions (EMB-O). However, Asian populations have a higher prevalence of ICAS although the incidence of ICAS-O remains unknown. AIS may result from either hemodynamic compromise in flow-limiting lesions or vessel occlusion secondary to plaque rupture and thrombosis. ICAS-O is more frequent in males, slightly younger populations, and in the posterior circulation. Clot burden tends to be lower and with often better collaterals due to the chronic nature of the stenosis. The EVT technique remains the same. A residual stenosis may remain, which should not be confused for vasospasm or focal dissection. Vasospasm can be differentiated by a 10 - to 20 -minute interval angiogram. ${ }^{78}$ Unlike EMB-O that shows progressive improvement in the caliber of the occluded segment, ICAS-O shows persistent stenosis or even reocclusion at CT/MRA 5 to 7 days after EVT. ${ }^{79}$ Presently, residual stenosis is best managed medically in light of the negative results of the SAMMPRIS (Stenting and Aggressive Medical Management for Preventing Recurrent stroke in Intracranial Stenosis) trial. ${ }^{80}$ Immediate initiation of glycoprotein IIb/IIIa inhibitors may prevent reocclusion. ${ }^{81}$ However, emergent stenting with or without angioplasty may play a role in residual critical stenoses. ${ }^{82}$

Distal occlusions: For occlusions of the M2 segments, contact aspiration may result in higher rate of successful recanalization and a lower risk of distal embolism. ${ }^{83}$ However, delivery of these larger-bore aspiration catheters may be impeded by proximal vessel tortuosity. Thrombus location at the M1-M2 junction or at an acute angle may result in suboptimal contact and poor aspiration. Further, the efficacy of aspiration drops rapidly with increase in number of attempts. In such cases, primary stentriever thrombectomy or early switching may be considered. ${ }^{83}$ For a thrombus extending from the M1 or basilar bifurcation, a dual-stentriever technique with deployment in a double-barrel Y-configuration is useful for simultaneous thrombectomy. ${ }^{84}$

Large DWI lesions: Patients with large DWI lesions > 60 or $70 \mathrm{~mL}$ are not necessarily exempt from EVT. Although the frequency remains low, EVT may result in a significantly higher probability of achieving modified Rankin scale (mRS) $0-3 .{ }^{85}$ EVT may be of benefit more in patients with isolated M1 MCA occlusions or lesions restricted to the superficial MCA territory than in those with carotid occlusions or deep MCA territory involvement. ${ }^{86}$ Perfusion studies are necessary to exclude oligemic tissue. Judicious patient selection is necessary.

Stroke with minimal symptoms: Minor stroke is defined by an NIHSS (National Institutes of Health Stroke Scale) score of $\leq 5$. The lack of major neurological deficit is due to presumably a relatively small penumbra and a large area of benign oligemia. The question arises, therefore, as to the necessity of treatment in such patients. However, the presence of an underlying large vessel occlusion is the main predictor of deterioration in such patients, resulting in poor outcomes in up to one-third. ${ }^{87,88}$ Further, slow-flowing collaterals, as assessed by either triple-phase computed tomographic angiography (CTA) or computed tomographic perfusion (CTP) source images, are associated with thrombus extension and increasing core. ${ }^{89}$ MT is thus a viable option in such patients and results in a favorable shift of NIHSS and higher rates of independence at discharge as well as at longterm follow-up. ${ }^{90}$

Tandem occlusions: Concurrent carotid stenting and embolectomy remain reasonable as per the AHA guidelines. However, controversies remain regarding the optimal approach. The antegrade/distal-to-proximal method reduces time to recanalization of the intracranial vessel, thus decreasing the duration of ischemia and reliance on collaterals. Alternatively, a retrograde/proximal-to-distal approach addresses the offending thromboembolic cervical plaque first, improving collateralization and theoretically reducing distal embolization while intracranial recanalization is being performed. ${ }^{91} \mathrm{~A}$ recent meta-analysis suggests no difference between either approach or between angioplasty and stenting of the extracranial lesion. ${ }^{92}$

Surgical embolectomy: In cases still within the time window, a minimally invasive and rapid surgical embolectomy (MIRSE) technique via a superciliary or supraorbital keyhole provides rapid access to the target artery. ${ }^{93}$ The role of extracranial-intracranial (EC-IC) bypass has been largely relegated to the prevention of recurrent stroke. ${ }^{94}$

\section{Complications}

Mechanical thrombectomy is associated with a major complication rate of up to approximately $15 \% .{ }^{95,96}$ Major complications can adversely affect functional outcomes, resulting in prolonged hospital stay, long-term disability, and even mortality. These are classified in - Table 10. The neurointerventionist must be cognizant of the potential complication for each step of the MT procedure. The risk of complications increases with prolongation of the procedure highlighting the importance of rapid recanalization.

The most common complication encountered is that of sICH. Though IVT is associated with a risk of systemic and intraparenchymal hemorrhage, EVT is associated with a higher risk of subarachnoid hemorrhage (SAH). Assessment and management of sICH is described in the next section. Arterial perforations (AP) occur at a frequency between 0.6 and $4.9 \%$ in the six recent RCTs. ${ }^{23,24,38-41}$ The risk of AP is increased during two critical times of the procedure: during "blind maneuvering" across the thrombus and while retrieving the stentriever. ${ }^{95}$ It is usually seen as extravasation. Management is as for any perforation-resisting the urge to withdraw the perforating device, reversal of heparin, inducing mild systemic hypotension, and tamponading with an intracranial balloon. Minor degrees of resultant SAH need not necessarily affect outcomes. ${ }^{96}$ Perforation of the cavernous ICA may 
Table 10 Complications of EVT in AIS

\begin{tabular}{|c|c|}
\hline \multirow{5}{*}{$\begin{array}{l}\text { Hemorrhagic } \\
\text { complications }\end{array}$} & - $\mathrm{sICH}$ \\
\hline & - $\mathrm{PH} 1 / 2$ or \\
\hline & - HI $1 / 2$ \\
\hline & - SAH \\
\hline & - IVH \\
\hline \multirow{4}{*}{$\begin{array}{l}\text { Device/procedure- } \\
\text { related complications }\end{array}$} & - Stent detachment/fracture \\
\hline & - Arterial dissection \\
\hline & - Carotid-cavernous fistula \\
\hline & - Arterial perforation \\
\hline \multirow[t]{2}{*}{ Distal NTE } & - Distal territory (NTE-D) \\
\hline & - New territory (NTE-N) \\
\hline \multirow[t]{6}{*}{ Others } & - Vessel vasospasm \\
\hline & $\begin{array}{l}\text { - Reocclusion/incomplete } \\
\text { recanalization }\end{array}$ \\
\hline & - Access site complications \\
\hline & - Anesthesia related \\
\hline & $\begin{array}{l}\text { Hypersensitivity-device } \\
\text { (Nickel) and contrast media }\end{array}$ \\
\hline & - Radiation-related risks \\
\hline
\end{tabular}

Abbreviations: AIS, acute ischemic stroke; EVT, endovascular treatment; HI, hemorrhagic infarction; IVH, intraventricular hemorrhage; NTE, nontarget embolization; PH, parenchymal hematoma; SAH, subarachnoid hemorrhage; $\mathrm{sICH}$, spontaneous intracerebral hemorrhage.

result in carotid-cavernous fistula as well. ${ }^{97}$ Irritation of the vessel may lead to vasospasm that occurred between 3.9 and 23\% in the six RCTs. ${ }^{23,24,38-41}$ Although usually asymptomatic, it must be treated when severe to prevent potential reocclusion. ${ }^{98}$ Off-label use of nimodipine, avoiding systemic hypotension, is reasonable. ${ }^{95}$ Arterial dissection can occur both intra- and extracranially during microcatheter or guide catheter navigation. Early recognition is necessary to modify the MT procedure and prevent extension or worsening. Management options included anticoagulant or dual-antiplatelet therapy when non-flow limiting or plasty or stenting when flow limiting. ${ }^{99}$ Unexpected stent detachment is associated with a higher risk of ICH, poor outcomes, and increased mortality. ${ }^{100,101}$ The probability increases with the number of passes and the manufacturer's instructions for use must be adhered to. ${ }^{95,102}$ Treatment options include leaving the stent in place if the vessel has opened, angioplasty if only partial vessel opening, using a second device for retrieval, and only if necessary surgical extraction. ${ }^{95}$ Other complications are managed as for any interventional procedure.

\section{Posttreatment Management}

Admission of the patient to a designated neurointensive care unit is preferred as protocolized and specialized care results in improved rates of good outcomes and better monitoring for complications. ${ }^{103}$

Failed or incomplete recanalization: Failure to achieve TICI $2 b / 3$ recanalizations results in persistence of the ischemic penumbra. Leptomeningeal collaterals require at least
24 hours to reach adequate capacity and measures need to be taken during this time to sustain them. ${ }^{104}$ Therapeutic hypertension improves both cerebral perfusion pressure and mean flow velocities and is a reasonable approach to augmenting collateral flow. Target to increase mean arterial pressure (MAP) by 10 to $20 \%$ above baseline or a maximum systolic blood pressure (SBP) of $185 \mathrm{~mm} \mathrm{Hg}$ if IV alteplase has already been given. Patients with ICH, congestive cardiac failure, or $\mathrm{SBP}>200 \mathrm{~mm} \mathrm{Hg}$ should be excluded. Targets may be reached by withholding antihypertensives, the use of vasopressor therapy (phenylephrine or norepinephrine is preferred), fluid expansion (bolus of $0.5-1 \mathrm{~L}$ followed by maintenance), and supine positioning (unless risk of aspiration, then maintain 30 degrees). ${ }^{105}$ Success of augmentation must be evaluated by testing for improvements of the NIHSS by at least $4 .{ }^{106}$ Continue collateral support for at least 24 hours with a gradual weaning thereafter. Failure to withstand weaning may require initiation of oral hypertensive agents such as fludrocortisone. ${ }^{105}$ Note, however, that the AHA guideline dismisses volume expansion in the treatment of AIS. ${ }^{4}$

Symptomatic ICH: Hemorrhagic transformation represents a continuum in reperfusion injury with breakdown of the blood-brain barrier. Symptomatic ICH refers to the contemporaneous neurologic worsening (NIHSS increase of 4 from baseline) with corresponding radiologic evidence of hemorrhage within 36 hours from treatment initiation. ${ }^{32}$ The relevance of hemorrhagic transformation is based on the radiologic appearance and is graded according to the European-Australasian Acute Stroke Study II (ECASS II) criteria with PH being symptomatic ( - Table 11) ${ }^{107}$ Though petechial hemorrhagic infarction is ischemic in nature, parenchymal hematomas are due to reperfusion injury. ${ }^{108} \mathrm{~A}$ third type of hemorrhage, extraischemic, that is, remote from the infarct and often multifocal, merits consideration of entities such as coagulopathies or amyloid angiopathy. ${ }^{108}$ Management involves reversal of coagulopathy, supportive therapy, and decompressive craniectomy if signs of significant mass effect ( $\mathrm{PH} 2$ ) are present.

Malignant infarction: Malignant infarction occurs in 1 to $10 \%$ of patients with an MCA stroke leading to depression of sensorium over the 24 to 48 hours. It is one of the most

Table 11 ECASS II hemorrhage grades

\begin{tabular}{|c|c|}
\hline Grade & Imaging criteria \\
\hline $\mathrm{HI}$ & $\begin{array}{l}\text { - Petechial hyperdensities in the } \\
\text { infarct bed but no mass effect }\end{array}$ \\
\hline - HI1 & - Small punctate petechiae \\
\hline - HI2 & - Confluent petechiae \\
\hline PH & $\begin{array}{l}\text { - Homogenously hyperdense } \\
\text { hematoma/coagulum }\end{array}$ \\
\hline - PH1 & - $\leq 30 \%$ of infarct bed, mild mass effect \\
\hline - $\mathrm{PH} 2$ & $\begin{array}{l}\text { - }>30 \% \text { of infarct bed with significant } \\
\text { mass effect or remote hemorrhage }\end{array}$ \\
\hline
\end{tabular}

Abbreviations: AIS, acute ischemic stroke; ECASS, European Cooperative Acute Stroke Study; EVT, endovascular treatment; HI, hemorrhagic infarction; $\mathrm{PH}$, parenchymal hematoma. 
dreaded complications having a mortality rate of nearly $80 \%{ }^{109}$ Favorable neurological outcomes and reduced mortality can still be achieved by decompressive craniectomy, but this needs correct timing. ${ }^{110}$ Clinical factors that were predictive of impending malignant infarction post-EVT were a high NIHSS ( $\geq 20$ or $\geq 15$ for left and right hemispheres respectively), a high admission BP, and hyperglycemia (with failure of control within 48 hours). ${ }^{111,112}$ Radiologically, the strongest predictor was a CT ASPECTS (Alberta Stroke Program Early CT Score) $\leq 5$ or a diffusion-weighted imaging (DWI) core volume of $>80 \mathrm{~mL}$ with a low sensitivity but high specificity. ${ }^{111,113}$

Other measures: Patients may be extubated based on the neurologist/anesthetist's assessment. Airway support and ventilator assistance may be continued if there is evidence of continued depressed sensorium or lack of airway protection secondary to bulbar dysfunction. Dysphagia screening with is necessary prior to initiation of oral medications or feeds. Continue supplemental oxygen if peripheral capillary oxygen saturation $\left(\mathrm{SpO}_{2}\right)$ is $<94 \%$. Control any hyperthermia with antipyretics. Though hypotension and hypovolemia correction is beneficial, the role of hemodilution, vasodilators, or flow augmentation strategies is controversial. Maintain sugars in the range of 140 to $180 \mathrm{mg} / \mathrm{dL}$ while preventing hypoglycaemia. ${ }^{105}$ Prevent sICH by maintaining SBP $<140$ to $160 \mathrm{~mm} \mathrm{Hg}$ while avoiding cerebral hypoperfusion with the use tightly titrated infusion of rapidly acting IV agents such as nicardipine, labetalol, or enalapril. ${ }^{105,114}$

Aspirin must be started within 24 to 48 hours from onset in all patients with AIS after ruling out hemorrhagic complications. ${ }^{4,105}$ Dual antiplatelets (with clopidogrel) are beneficial in patients with minor stroke for secondary stroke prevention. Glycoprotein 2b/3a inhibitors such as abciximab are contraindicated. Anticoagulation has no role of in AIS with ELVO but may be indicated in extracranial nonocclusive thrombi. ${ }^{105}$

\section{Posttreatment Imaging}

Posttreatment imaging is aimed at establishing the size of the final infarct and the presence of hemorrhage. ${ }^{115}$ Apart from age, the final infarct volume (FIV) is a better predictor of neurologic outcomes than even revascularization grade. ${ }^{116}$ Indeed, revascularization achieves good outcomes only because it reduces FIV. In cases of incomplete recanalization, a 24-hour CT may underestimate FIV due to ongoing infarction. The role of the 24-hour CT is to rule out hemorrhagic transformation. A 7- or 30-day CT/fluid-attenuated inversion recovery (FLAIR) is best to look for the FIV because infarct growth is insignificant beyond this point. ${ }^{117,118}$ Parenchymal contrast medium staining may be differentiated from ICH by means of serial noncontrast CTs, susceptibility-weighted imaging (SWI), or dual-energy CT. ${ }^{105}$

\section{Quality Control}

The joint statement by the American Society of Neuroradiology with the Society for Neurointerventional Surgery and others have given training and quality control guidelines for the interventional neuroradiologist. ${ }^{119}$ As a basic minimum, interventionists are expected to achieve successful recanalization of TICI $2 \mathrm{~b} / 3$ in at least $60 \%$ of cases, embolization to new territories in $<15 \%$ of cases, and an sICH (i.e., PH) rate of $<10 \%$.

\section{Conclusion}

Significant improvements have been made in clinical outcomes following AIS with ELVO, largely due to advances in endovascular techniques. Apart from endovascular radiology, interventionists must be competent in aspects of vascular neurology, diagnostic stroke radiology, and cerebrovascular neurosurgery to make the best decision for the patient. Further progress is dependent on evolving improved devices and techniques, a harmoniously integrated multidisciplinary team, enhanced transport systems, and increased public awareness.

\section{Conflict of Interest}

None.

\section{References}

1 El Tawil S, Cheripelli B, Huang X, et al. How many stroke patients might be eligible for mechanical thrombectomy? Eur Stroke J 2016;1(4):264-271

2 McMeekin P, White P, James MA, Price CI, Flynn D, Ford GA. Estimating the number of UK stroke patients eligible for endovascular thrombectomy. Eur Stroke J 2017;2(4):319-326

3 Tsivgoulis G, Goyal N, Mikulik R, et al. Eligibility for mechanical thrombectomy in acute ischemic stroke: a phase IV multi-center screening log registry. J Neurol Sci 2016;371:96-99

4 Powers WJ, Rabinstein AA, Ackerson T, et al; American Heart Association Stroke Council. 2018 Guidelines for the early management of patients with acute ischemic stroke: a guideline for healthcare professionals from the American Heart Association/ American Stroke Association. Stroke 2018;49(3):e46-e110

5 Anderson CS, Robinson T, Lindley RI, et al; ENCHANTED Investigators and Coordinators. Low-dose versus standard-dose intravenous alteplase in acute ischemic stroke. $\mathrm{N}$ Engl J Med 2016;374(24):2313-2323

6 Sila C. Finding the right t-PA dose for Asians with acute ischemic stroke. N Engl J Med 2016;374(24):2389-2390

7 Huang X, Cheripelli BK, Lloyd SM, et al. Alteplase versus tenecteplase for thrombolysis after ischaemic stroke (ATTEST): a phase 2, randomised, open-label, blinded endpoint study. Lancet Neurol 2015;14(4):368-376

8 Campbell BCV, Mitchell PJ, Churilov L, et al; EXTEND-IA TNK Investigators. Tenecteplase versus alteplase before thrombectomy for ischemic stroke. N Engl J Med 2018;378(17):1573-1582

9 Emberson J, Lees KR, Lyden P, et al; Stroke Thrombolysis Trialists' Collaborative Group. Effect of treatment delay, age, and stroke severity on the effects of intravenous thrombolysis with alteplase for acute ischaemic stroke: a meta-analysis of individual patient data from randomised trials. Lancet 2014;384(9958):1929-1935

10 Bhatia R, Hill MD, Shobha N, et al. Low rates of acute recanalization with intravenous recombinant tissue plasminogen activator in ischemic stroke: real-world experience and a call for action. Stroke 2010;41(10):2254-2258

11 Meairs S. Sonothrombolysis. Front Neurol Neurosci 2015; 36:83-93

12 Alexandrov AV, Molina CA, Grotta JC, et al; CLOTBUST Investigators. Ultrasound-enhanced systemic thrombolysis for acute ischemic stroke. N Engl J Med 2004;351(21):2170-2178

13 Nacu A, Kvistad CE, Naess H, et al. NOR-SASS (Norwegian Sonothrombolysis in Acute Stroke Study): randomized controlled 
contrast-enhanced sonothrombolysis in an unselected acute ischemic stroke population. Stroke 2017;48(2):335-341

14 Reinhard M, Taschner CA, Hörsch N, et al. Endovascular treatment versus sonothrombolysis for acute ischemic stroke. Cerebrovasc Dis 2015;40(5-6):205-214

15 Aaron S, Mani S, Prabhakar AT, et al. Sonothrombolysis for acute ischemic stroke-break on through to the other side. Neurol India 2017;65(1):52-57

16 Barreto AD, Alexandrov AV, Shen L, et al. CLOTBUST-Hands Free: pilot safety study of a novel operator-independent ultrasound device in patients with acute ischemic stroke. Stroke 2013;44(12):3376-3381

17 Mistry EA, Mistry AM, Nakawah MO, et al. Mechanical thrombectomy outcomes with and without intravenous thrombolysis in stroke patients: a meta-analysis. Stroke 2017;48(9):2450-2456

18 Mazighi M, Meseguer E, Labreuche J, Amarenco P. Bridging therapy in acute ischemic stroke: a systematic review and meta-analysis. Stroke 2012;43(5):1302-1308

19 Bellwald S, Weber R, Dobrocky T, et al. Direct mechanical intervention versus bridging therapy in stroke patients eligible for intravenous thrombolysis: a pooled analysis of 2 registries. Stroke 2017;48(12):3282-3288

20 Raza SA, Rangaraju S. A review of pre-intervention prognostic scores for early prognostication and patient selection in endovascular management of large vessel occlusion stroke. Interv Neurol 2018;7(3-4):171-181

21 Rangaraju S, Aghaebrahim A, Streib C, et al. Pittsburgh Response to Endovascular therapy (PRE) score: optimizing patient selection for endovascular therapy for large vessel occlusion strokes. J Neurointerv Surg 2015;7(11):783-788

22 Goyal M, Fargen KM, Menon BK. Acute stroke, Bayes' theorem and the art and science of emergency decision-making. J Neurointerv Surg 2014;6(4):256-259

23 Saver JL, Goyal M, Bonafe A, et al; SWIFT PRIME Investigators. Solitaire ${ }^{\mathrm{TM}}$ with the Intention for Thrombectomy as Primary Endovascular Treatment for Acute Ischemic Stroke (SWIFT PRIME) trial: protocol for a randomized, controlled, multicenter study comparing the Solitaire revascularization device with IV tPA with IV tPA alone in acute ischemic stroke. Int J Stroke 2015;10(3):439-448

24 Berkhemer OA, Fransen PS, Beumer D, et al; MR CLEAN Investigators. A randomized trial of intraarterial treatment for acute ischemic stroke. N Engl J Med 2015;372(1):11-20

25 Pfaff JAR, Schönenberger S, Nagel S, et al. Effect of general anesthesia versus conscious sedation for stroke thrombectomy on angiographic workflow in a randomized trial: a post hoc analysis of the SIESTA trial. Radiology 2018;286(3):1016-1021

26 Brinjikji W, Pasternak J, Murad MH, et al. Anesthesia-related outcomes for endovascular stroke revascularization: a systematic review and meta-analysis. Stroke 2017;48(10): 2784-2791

27 Bekelis K, Missios S, MacKenzie TA, Tjoumakaris S, Jabbour P. Anesthesia technique and outcomes of mechanical thrombectomy in patients with acute ischemic stroke. Stroke 2017;48(2):361-366

28 Anastasian $\mathrm{ZH}$. Anaesthetic management of the patient with acute ischaemic stroke. Br J Anaesth 2014;113Suppl 2 :ii9-ii16

29 Schönenberger S, Uhlmann L, Hacke W, et al. Effect of conscious sedation vs general anesthesia on early neurological improvement among patients with ischemic stroke undergoing endovascular thrombectomy: a randomized clinical trial. JAMA 2016;316(19):1986-1996

30 Fandino $\mathrm{W}$. The anesthesiologist, rather than the anesthesia, may influence the outcomes following stroke thrombectomy. AJNR Am J Neuroradiol 2018;39(2):E35

31 Nahab F, Walker GA, Dion JE, Smith WS. Safety of periprocedural heparin in acute ischemic stroke endovascular therapy: the multi MERCI trial. J Stroke Cerebrovasc Dis 2012;21(8):790-793

32 Furlan A, Higashida R, Wechsler L, et al. Intra-arterial prourokinase for acute ischemic stroke. The PROACT II study: a randomized controlled trial. Prolyse in acute cerebral thromboembolism. JAMA 1999;282(21):2003-2011

33 Alshekhlee A, Pandya DJ, English J, et al. Merci mechanical thrombectomy retriever for acute ischemic stroke therapy: literature review. Neurology 2012;79(13 Suppl 1):S126-S134

34 Smith WS, Sung G, Saver J, et al; Multi MERCI Investigators. Mechanical thrombectomy for acute ischemic stroke: final results of the multi MERCI trial. Stroke 2008;39(4):1205-1212

35 Smith WS, Sung G, Starkman S, et al; MERCI Trial Investigators. Safety and efficacy of mechanical embolectomy in acute ischemic stroke: results of the MERCI trial. Stroke 2005;36(7):1432-1438

36 Hussain SI, Zaidat OO, Fitzsimmons BF. The Penumbra system for mechanical thrombectomy in endovascular acute ischemic stroke therapy. Neurology 2012;79(13 Suppl 1):S135-S141

37 Penumbra Pivotal Stroke Trial Investigators. The penumbra pivotal stroke trial: safety and effectiveness of a new generation of mechanical devices for clot removal in intracranial large vessel occlusive disease. Stroke 2009;40(8):2761-2768

38 Campbell BC, Mitchell PJ, Kleinig TJ, et al; EXTEND-IA Investigators. Endovascular therapy for ischemic stroke with perfusion-imaging selection. N Engl J Med 2015;372(11):1009-1018

39 Goyal M, Demchuk AM, Menon BK, et al; ESCAPE Trial Investigators. Randomized assessment of rapid endovascular treatment of ischemic stroke. N Engl J Med 2015;372(11):1019-1030

40 Jovin TG, Chamorro A, Cobo E, et al; REVASCAT Trial Investigators. Thrombectomy within 8 hours after symptom onset in ischemic stroke. N Engl J Med 2015;372(24):2296-2306

41 Bracard S, Ducrocq X, Mas JL, et al; THRACE investigators. Mechanical thrombectomy after intravenous alteplase versus alteplase alone after stroke (THRACE): a randomised controlled trial. Lancet Neurol 2016;15(11):1138-1147

42 Boyle K, Joundi RA, Aviv RI. An historical and contemporary review of endovascular therapy for acute ischemic stroke. Neurovascular Imaging 2017;3(1):1

43 Raychev R, Jahan R, Saver JL, et al. Microcatheter contrast injection in stent retriever neurothrombectomy is safe and useful: insights from SWIFT PRIME. J Neurointerv Surg 2017

44 Haussen DC, Rebello LC, Nogueira RG. Optimizating clot retrieval in acute stroke: the push and fluff technique for closed-cell stentrievers. Stroke 2015;46(10):2838-2842

45 Haussen DC, Al-Bayati AR, Grossberg JA, et al. Longer stent retrievers enhance thrombectomy performance in acute stroke. J Neurointerv Surg 2018;neurintsurg-2018-013918

46 Kannath SK, Rajan JE, Sylaja PN, et al. Dwell time of stentriever influences complete revascularization and first-pass TICI 3 revascularization in acute large vessel occlusive stroke. World Neurosurg 2018;110:169-173

47 Wadood A. Brief overview on Nitinol as biomaterial. Adv Mater Sci Eng 2016;20(16):9

48 Gralla J, Schroth G, Remonda L, Nedeltchev K, Slotboom J, Brekenfeld C. Mechanical thrombectomy for acute ischemic stroke: thrombus-device interaction, efficiency, and complications in vivo. Stroke 2006;37(12):3019-3024

49 Sacks D, Baxter B, Campbell BCV, et al. Multisociety consensus quality improvement revised consensus statement for endovascular therapy of acute ischemic stroke: From the American Association of Neurological Surgeons (AANS), American Society of Neuroradiology (ASNR), Cardiovascular and Interventional Radiology Society of Europe (CIRSE), Canadian Interventional Radiology Association (CIRA), Congress of Neurological Surgeons (CNS), European Society of Minimally Invasive Neurological Therapy (ESMINT), European Society of Neuroradiology (ESNR), European Stroke Organization (ESO), Society for 
Cardiovascular Angiography and Interventions (SCAI), Society of Interventional Radiology (SIR), Society of NeuroInterventional Surgery (SNIS), and World Stroke Organization (WSO). J Vasc Interv Radiol 2018;29(4):441-453

50 Zerna C, Assis Z, d'Esterre CD, Menon BK, Goyal M. Imaging, intervention, and workflow in acute ischemic stroke: the Calgary approach. AJNR Am J Neuroradiol 2016;37(6):978-984

51 Mokin M, Setlur Nagesh SV, Ionita CN, Levy EI, Siddiqui AH. Comparison of modern stroke thrombectomy approaches using an in vitro cerebrovascular occlusion model. AJNR Am J Neuroradiol 2015;36(3):547-551

52 Pereira VM, Narata AP, Gonzalez AM, Sztajzel R, Lovblad KO. Use of stentrievers in acute stroke: tips, tricks, and current results. Tech Vasc Interv Radiol 2012;15(1):68-77

53 Kang DH, Hwang YH, Kim YS, Park J, Kwon O, Jung C. Direct thrombus retrieval using the reperfusion catheter of the penumbra system: forced-suction thrombectomy in acute ischemic stroke. AJNR Am J Neuroradiol 2011;32(2):283-287

54 Turk AS, Spiotta A, Frei D, et al. Initial clinical experience with the ADAPT technique: a direct aspiration first pass technique for stroke thrombectomy. J Neurointerv Surg 2014;6(3):231-237

55 Turk AS, Frei D, Fiorella D, et al. ADAPT FAST study: a direct aspiration first pass technique for acute stroke thrombectomy. J Neurointerv Surg 2014;6(4):260-264

56 Yoo AJ, Andersson T. Thrombectomy in acute ischemic stroke: challenges to procedural success. J Stroke 2017;19(2):121-130

57 Alawieh A, Pierce AK, Vargas J, et al. The golden $35 \mathrm{~min}$ of stroke intervention with ADAPT: effect of thrombectomy procedural time in acute ischemic stroke on outcome. J Neurointerv Surg 2018;10(3):213-220

58 Lapergue B, Blanc R, Gory B, et al; ASTER Trial Investigators. Effect of endovascular contact aspiration vs stent retriever on revascularization in patients with acute ischemic stroke and large vessel occlusion: the ASTER randomized clinical trial. JAMA 2017;318(5):443-452

59 Humphries W, Hoit D, Doss VT, et al. Distal aspiration with retrievable stent assisted thrombectomy for the treatment of acute ischemic stroke. J Neurointerv Surg 2015;7(2):90-94

60 Delgado Almandoz JE, Kayan Y, Young ML, et al. Comparison of clinical outcomes in patients with acute ischemic strokes treated with mechanical thrombectomy using either Solumbra or ADAPT techniques. J Neurointerv Surg 2016;8(11):1123-1128

61 Stampfl S, Pfaff J, Herweh C, et al. Combined proximal balloon occlusion and distal aspiration: a new approach to prevent distal embolization during neurothrombectomy. J Neurointerv Surg 2017;9(4):346-351

62 Maegerlein C, Mönch S, Boeckh-Behrens T, et al. PROTECT: PRoximal balloon Occlusion TogEther with direCt Thrombus aspiration during stent retriever thrombectomy - evaluation of a double embolic protection approach in endovascular stroke treatment. J Neurointerv Surg 2017;neurintsurg-2017-013558

63 Kallmes DF, Siddiqui AH, Ansari SA, Liebeskind DS, Zaidat OO. Aspiring to an improved aspiration literature. J Neurointerv Surg 2018; neurintsurg-2018-014046

64 Fargen KM, Mocco J, Gobin YP. The Lazarus Funnel: a blinded prospective randomized in vitro trial of a novel CE-marked thrombectomy assist device. J Neurointerv Surg 2016;8(1):66-68

65 Mokin M, Setlur Nagesh SV, Ionita CN, Mocco J, Siddiqui AH. Stent retriever thrombectomy with the Cover accessory device versus proximal protection with a balloon guide catheter: in vitro stroke model comparison. J Neurointerv Surg 2016;8(4):413-417

66 Duffy S, Farrell M, McArdle K, et al. Novel methodology to replicate clot analogs with diverse composition in acute ischemic stroke. J Neurointerv Surg 2017;9(5):486-491
67 De Meyer SF, Andersson T, Baxter B, et al; Clot Summit Group. Analyses of thrombi in acute ischemic stroke: a consensus statement on current knowledge and future directions. Int J Stroke 2017;12(6):606-614

68 Kim SK, Yoon W, Kim TS, Kim HS, Heo TW, Park MS. Histologic analysis of retrieved clots in acute ischemic stroke: correlation with stroke etiology and gradient-echo MRI. AJNR Am J Neuroradiol 2015;36(9):1756-1762

69 Boeckh-Behrens T, Kleine JF, Zimmer C, et al. Thrombus histology suggests cardioembolic cause in cryptogenic stroke. Stroke 2016;47(7):1864-1871

70 Boeckh-Behrens T, Schubert M, Förschler A, et al. The impact of histological clot composition in embolic stroke. Clin Neuroradiol 2016;26(2):189-197

71 Brinjikji W, Duffy S, Burrows A, et al. Correlation of imaging and histopathology of thrombi in acute ischemic stroke with etiology and outcome: a systematic review. J Neurointerv Surg 2017;9(6):529-534

72 Li Q Davis S, Mitchell P, Dowling R, Yan B. Proximal hyperdense middle cerebral artery sign predicts poor response to thrombolysis. PLoS One 2014;9(5):e96123

73 Khatri P, Neff J, Broderick JP, Khoury JC, Carrozzella J, Tomsick T; IMS-I Investigators. Revascularization end points in stroke interventional trials: recanalization versus reperfusion in IMS-I. Stroke 2005;36(11):2400-2403

74 Mori E, Yoneda Y, Tabuchi M, et al. Intravenous recombinant tissue plasminogen activator in acute carotid artery territory stroke. Neurology 1992;42(5):976-982

75 Suh SH, Cloft HJ, Fugate JE, Rabinstein AA, Liebeskind DS, Kallmes DF. Clarifying differences among thrombolysis in cerebral infarction scale variants: is the artery half open or half closed? Stroke 2013;44(4):1166-1168

76 Qureshi AI. New grading system for angiographic evaluation of arterial occlusions and recanalization response to intra-arterial thrombolysis in acute ischemic stroke. Neurosurgery 2002;50(6):1405-1414, discussion 1414-1415

77 Dargazanli C, Consoli A, Barral M, et al. Impact of modified TICI 3 versus modified TICI $2 \mathrm{~b}$ reperfusion score to predict good outcome following endovascular therapy. AJNR Am J Neuroradiol 2017;38(1):90-96

78 Kim YW, Hong JM, Park DG, et al. Effect of intracranial atherosclerotic disease on endovascular treatment for patients with acute vertebrobasilar occlusion. AJNR Am J Neuroradiol 2016;37(11):2072-2078

79 Lee JS, Hong JM, Kim JS. Diagnostic and therapeutic strategies for acute intracranial atherosclerosis-related occlusions. J Stroke 2017;19(2):143-151

80 Chimowitz MI, Lynn MJ, Derdeyn CP, et al; SAMMPRIS Trial Investigators. Stenting versus aggressive medical therapy for intracranial arterial stenosis. $\mathrm{N}$ Engl J Med 2011;365(11):993-1003

81 Yoon W, Kim SK, Park MS, Kim BC, Kang HK. Endovascular treatment and the outcomes of atherosclerotic intracranial stenosis in patients with hyperacute stroke. Neurosurgery 2015;76(6):680-686, discussion 686

82 Moon Kim B. Refractory occlusion to stentriever thrombectomy: etiological considerations and suggested solutions. In: Acute Ischemic Stroke Singapore: Springer Singapore; 2017:213-226

83 Kim YW, Son S, Kang DH, Hwang YH, Kim YS. Endovascular thrombectomy for M2 occlusions: comparison between forced arterial suction thrombectomy and stent retriever thrombectomy. J Neurointerv Surg 2017;9(7):626-630

84 Patro SN, Iancu D. Dual-stent retrieval for mechanical thrombectomy of refractory clot in acute stroke as a rescue technique. CMAJ 2017;189(17):E634-E637 
85 Nah HW, Kim DH, Kang M, Choi JH, Park HS, Cha JK. Thrombolysis in large diffusion-weighted imaging lesions: lower chance but still a chance. J Stroke Cerebrovasc Dis 2018;27(6):1511-1516

86 Gautheron V, Xie Y, Tisserand M, et al. Outcome after reperfusion therapies in patients with large baseline diffusion-weighted imaging stroke lesions: a THRACE trial (Mechanical Thrombectomy After Intravenous Alteplase Versus Alteplase Alone After Stroke) subgroup analysis. Stroke 2018;49(3):750-753

87 Haussen DC, Bouslama M, Grossberg JA, et al. Too good to intervene? Thrombectomy for large vessel occlusion strokes with minimal symptoms: an intention-to-treat analysis. J Neurointerv Surg 2017;9(10):917-921

88 Dargazanli C, Arquizan C, Gory B, et al; ETIS REGISTRY Investigators. Mechanical thrombectomy for minor and mild stroke patients harboring large vessel occlusion in the anterior circulation: a multicenter cohort study. Stroke 2017;48(12):3274-3281

89 Zhang R, Zhou Y, Yan S, Zhang S, Ding X, Lou M. Slow collateral flow is associated with thrombus extension in patients with acute large-artery occlusion. AJNR Am J Neuroradiol 2018;39(6):1088-1092

90 Haussen DC, Lima FO, Bouslama M, et al. Thrombectomy versus medical management for large vessel occlusion strokes with minimal symptoms: an analysis from STOP Stroke and GESTOR cohorts. J Neurointerv Surg 2018;10(4):325-329

91 Rangel-Castilla L, Rajah GB, Shakir HJ, et al. Management of acute ischemic stroke due to tandem occlusion: should endovascular recanalization of the extracranial or intracranial occlusive lesion be done first? Neurosurg Focus 2017;42(4):E16

92 Wilson MP, Murad MH, Krings T, et al. Management of tandem occlusions in acute ischemic stroke-intracranial versus extracranial first and extracranial stenting versus angioplasty alone: a systematic review and meta-analysis. J Neurointerv Surg 2018;neurintsurg-2017-013707

93 Park J. Surgical embolectomy for acute ischemic stroke. In: Park J, ed. Acute Ischemic Stroke: Medical, Endovascular, and Surgical Techniques. Singapore: Springer Singapore; 2017:229-245

94 Kim JE, Jeon JP, Cho W-S. Bypass Surgery. In: Park J, ed. Acute Ischemic Stroke: Medical, Endovascular, and Surgical Techniques. Singapore: Springer Singapore; 2017:247-254

95 Balami JS, White PM, McMeekin PJ, Ford GA, Buchan AM. Complications of endovascular treatment for acute ischemic stroke: prevention and management. Int J Stroke 2018;13(4):348-361

96 Behme D, Gondecki L, Fiethen S, Kowoll A, Mpotsaris A, Weber W. Complications of mechanical thrombectomy for acute ischemic stroke-a retrospective single-center study of 176 consecutive cases. Neuroradiology 2014;56(6):467-476

97 Akpinar SH, Yilmaz G. Periprocedural complications in endovascular stroke treatment. BrJ Radiol 2016;89(1057):20150267

98 Gupta R. Arterial vasospasm during mechanical thrombectomy for acute stroke. J Neuroimaging 2009;19(1):61-64

99 Davis MC, Deveikis JP, Harrigan MR. Clinical presentation, imaging, and management of complications due to neurointerventional procedures. Semin Intervent Radiol 2015;32(2):98-107

100 Yub Lee S, Won Youn S, Kyun Kim H, Rok Do Y. Inadvertent detachment of a retrievable intracranial stent: review of manufacturer and user facility device experience. Neuroradiol J 2015;28(2):172-176

101 Castaño C, Dorado L, Remollo S, et al. Unwanted detachment of the Solitaire device during mechanical thrombectomy in acute ischemic stroke. J Neurointerv Surg 2016; neurintsurg-2015-012156

102 Masoud $\mathrm{H}$, Nguyen $\mathrm{TN}$, Martin CO, et al. Inadvertent stent retriever detachment: a multicenter case series and review of device experience FDA reports. Interv Neurol 2016;4(3-4):75-82
103 Collaborative systematic review of the randomised trials of organised inpatient (stroke unit) care after stroke. Stroke Unit Trialists' Collaboration. BMJ 1997;314(7088):1151-1159

104 Christoforidis GA, Vakil P, Ansari SA, Dehkordi FH, Carroll TJ. Impact of pial collaterals on infarct growth rate in experimental acute ischemic stroke. AJNR Am J Neuroradiol 2017;38(2):270-275

105 Leslie-Mazwi T, Chen M, Yi J, et al; Standards and Guidelines committee of the Society of NeuroInterventional Surgery (SNIS). Post-thrombectomy management of the ELVO patient: guidelines from the Society of NeuroInterventional Surgery. J Neurointerv Surg 2017;9(12):1258-1266

106 Rordorf G, Koroshetz WJ, Ezzeddine MA, Segal AZ, Buonanno FS. A pilot study of drug-induced hypertension for treatment of acute stroke. Neurology 2001;56(9):1210-1213

107 Hacke W, Kaste M, Fieschi C, et al; Second European-Australasian Acute Stroke Study Investigators. Randomised double-blind placebo-controlled trial of thrombolytic therapy with intravenous alteplase in acute ischaemic stroke (ECASS II) Lancet 1998;352(9136):1245-1251

108 Trouillas P, von Kummer R. Classification and pathogenesis of cerebral hemorrhages after thrombolysis in ischemic stroke. Stroke 2006;37(2):556-561

109 Hacke W, Schwab S, Horn M, Spranger M, De Georgia M, von Kummer R. 'Malignant' middle cerebral artery territory infarction: clinical course and prognostic signs. Arch Neurol 1996;53(4):309-315

110 Vahedi K, Hofmeijer J, Juettler E, et al; DECIMAL, DESTINY, and HAMLET investigators. Early decompressive surgery in malignant infarction of the middle cerebral artery: a pooled analysis of three randomised controlled trials. Lancet Neurol 2007;6(3):215-222

111 Davoli A, Motta C, Koch G, et al. Pretreatment predictors of malignant evolution in patients with ischemic stroke undergoing mechanical thrombectomy. J Neurointerv Surg 2017

112 Krieger DW, Demchuk AM, Kasner SE, Jauss M, Hantson L. Early clinical and radiological predictors of fatal brain swelling in ischemic stroke. Stroke 1999;30(2):287-292

113 Thomalla G, Hartmann F, Juettler E, et al; Clinical Trial Net of the German Competence Network Stroke. Prediction of malignant middle cerebral artery infarction by magnetic resonance imaging within 6 hours of symptom onset: A prospective multicenter observational study. Ann Neurol 2010;68(4):435-445

114 He J, Zhang Y, Xu T, et al; CATIS Investigators. Effects of immediate blood pressure reduction on death and major disability in patients with acute ischemic stroke: the CATIS randomized clinical trial. JAMA 2014;311(5):479-489

115 Brinjikji W, Rabinstein A, Cloft HJ, Lanzino G, Kallmes DF. Recently published stroke trials: what the radiologist needs to know. Radiology 2015;276(1):8-11

116 Zaidi SF, Aghaebrahim A, Urra X, et al. Final infarct volume is a stronger predictor of outcome than recanalization in patients with proximal middle cerebral artery occlusion treated with endovascular therapy. Stroke 2012;43(12):3238-3244

117 Krongold M, Almekhlafi MA, Demchuk AM, Coutts SB, Frayne $\mathrm{R}$, Eilaghi A. Final infarct volume estimation on 1-week follow-up MR imaging is feasible and is dependent on recanalization status. Neuroimage Clin 2014;7:1-6

118 Gaudinski MR, Henning EC, Miracle A, Luby M, Warach S, Latour LL. Establishing final infarct volume: stroke lesion evolution past 30 days is insignificant. Stroke 2008;39(10):2765-2768

119 Lavine SD, Cockroft K, Hoh B, et al. Training guidelines for endovascular ischemic stroke intervention: an international multi-society consensus document. AJNR Am J Neuroradiol 2016;37(4):E31-E34 